\title{
The Competitiveness and Complementarities of Agriculture Trade among ASEAN-5 Countries: An Empirical Analysis
}

\author{
Mohammed Faiz Shaul Hamid ${ }^{1}$ \& Mohamed Aslam ${ }^{1}$ \\ ${ }^{1}$ University of Malaya, Malaysia \\ Correspondence: Mohammed Faiz Shaul Hamid, Asia-Europe Institute, University of Malaya, 50603 Kuala \\ Lumpur, Malaysia. Tel: 601-7314-1147. E-mail: faiz.shaul@gmail.com
}

Received: May 29, 2017

Accepted: June 21, 2017

Online Published: July 10, 2017

doi:10.5539/ijef.v9n8p88

URL: https://doi.org/10.5539/ijef.v9n8p88

\begin{abstract}
The trade of agriculture products between ASEAN countries has grown rapidly since the establishment of the ASEAN Free Trade Area (AFTA). By using the Revealed Comparative Advantage (RCA) and Intra-Industry Trade (IIT) indexes, this study empirically analyses the competitiveness and complementarities among the ASEAN-5 countries for agriculture products. The results shows that IIT is relatively limited and RCA for Thailand, Indonesia and Vietnam revealed intense competition among each other in the agriculture sector. Interestingly, the results also showed that Vietnam strongly competed against Thailand and Indonesia, which was detrimental towards both these countries and resulted to these countries losing their competitiveness in several product categories. ASEAN-5 countries have also shown diverse trends of competitiveness for each product category in the agriculture industry and the level of competitiveness coupled with low intra-industry trade reflect that there are policy mismatches that curb further trade integration in the industry despite several efforts under AFTA.
\end{abstract}

Keywords: agriculture trade, ASEAN free trade area, revealed comparative advantage

\section{Introduction}

The agriculture sector remains as one of the most important sector to ASEAN countries. Even prior to the establishment of ASEAN in 1967, most countries in the region were predominantly dependent on agriculture sector. Due to similar weather, land availability and demand for similar agriculture produces, ASEAN countries typically produce similar products and the surpluses from the domestic demand were then exported. This formed the basis of agriculture trade between ASEAN countries.

As a result of technological advancements coupled with efforts to upgrade and uplift the agriculture sector, there are today several agriculture products from some ASEAN countries around the world and nevertheless, some countries, such as Thailand and Vietnam have emerged as the most important exporter of rice in the world, which is an important staple food in many countries in Asia.

Table 1. Share of agriculture sector to all products exports of ASEAN-5 countries (values in USD thousand)

\begin{tabular}{lccccc}
\hline & $\mathbf{2 0 0 1}$ & $\mathbf{2 0 0 5}$ & $\mathbf{2 0 0 8}$ & $\mathbf{2 0 1 1}$ & $\mathbf{2 0 1 4}$ \\
\hline Exports of ASEAN-5 & $5,862,747$ & $9,414,932$ & $19,134,877$ & $25,527,156$ & $26,311,183$ \\
All Exports of ASEAN-5 to the World & $191,881,734$ & $328,867,192$ & $492,805,612$ & $611,760,305$ & $691,135,682$ \\
Share of Exports (\%) & $3 \%$ & $3 \%$ & $4 \%$ & $4 \%$ & $4 \%$ \\
\hline
\end{tabular}

As shown in Table 1, the exports of ASEAN-5 (Note 1) countries in the agriculture sector increased nearly 5 times from year 2001 to 2014 . The total share of agriculture sector however remained in the range of 3-4\% only and this signals, that despite the increase in value of exports, the agriculture sector did not grow as rapidly as total ASEAN-5 exports to the world. The agriculture export dependence of the Southeast Asian region has also decreased to the low dependence level owing to the export diversification of the countries in the region beginning from 1990s. 
Table 2. Value of agriculture exports of individual ASEAN-5 countries (values in USD thousand)

\begin{tabular}{lccccc}
\hline ASEAN-5 & $\mathbf{2 0 0 1}$ & $\mathbf{2 0 0 5}$ & $\mathbf{2 0 0 8}$ & $\mathbf{2 0 1 1}$ & $\mathbf{2 0 1 4}$ \\
\hline Malaysia & 309,343 & 365,224 & 526,995 & 767,455 & 877,112 \\
Thailand & $2,576,589$ & $3,708,913$ & $8,353,316$ & $10,398,967$ & $10,619,249$ \\
Indonesia & 738,553 & $1,295,998$ & $2,186,816$ & $2,706,674$ & $3,227,532$ \\
Philippines & 544,429 & 690,044 & 904,803 & $1,204,917$ & $2,051,762$ \\
Vietnam & $1,693,833$ & $3,354,753$ & $7,162,947$ & $10,449,143$ & $9,535,528$ \\
\hline
\end{tabular}

Yet, the exports of the agriculture products have shown an increasing trend. As shown in Table 2, the values of export for ASEAN-5 countries increased from year 2001 to 2014. Thailand's export value increased from USD2.6 billion in 2001 to USD10.6 billion in 2014 and Vietnam made a bigger leap from USD1.7 billion to USD9.5billion for the same period of time. The increase in agriculture exports among ASEAN-5 countries has also shown an increasingly intense competition between Thailand and Vietnam. Figure 1 shows Vietnam's value of exports that was closely following the value of Thailand up to year 2010, when Vietnam overtook Thailand's value. The competition between both these countries still exist until today, mostly due to the exports of rice.

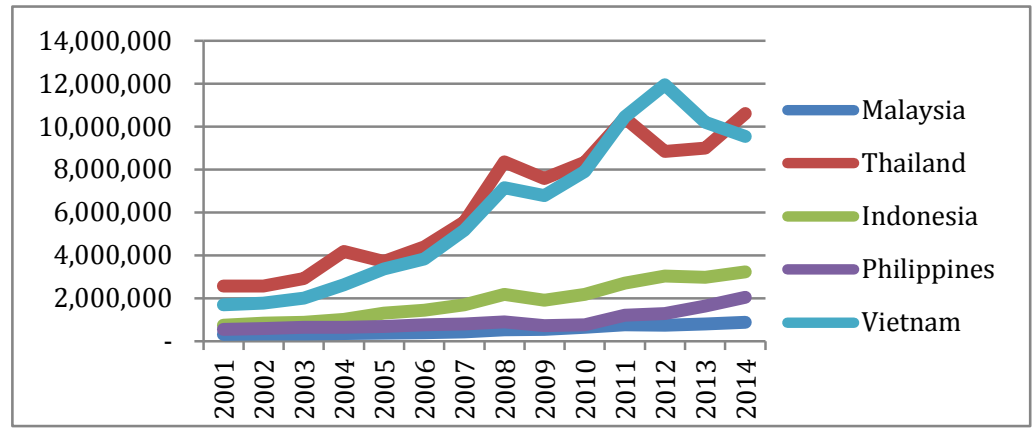

Figure 1. Value of agriculture exports of individual ASEAN-5 countries against years (2001-2014)

In terms of product categories as shown in Table 3, HS100- Maize (corn), Rice, Buckwheat, millet and canary seed, Oats, Barley, Wheat, and Rye recorded the highest value especially due to the exports of rice. This was followed by HS090- Coffee, Tea, Pepper, Capsicum, Cinnamon Flowers, Cloves, Nutmeg, Seeds of Anise, Vanilla. The value for this product category, particularly led by coffee and tea, climbed to USD6.3 billion in 2014, which shows rapid growth, and it also complements the concentration of rice exports. Another product that also complements rice export is HS080- Nuts, Citrus Fruits, Banana, Melons, Grapes, Apricots, and Apples. ASEAN's export in this category increased mainly due to the exports of local fruits found in many ASEAN countries, such as banana, pineapple and watermelon.

Table 3. Top 5 agriculture products (HS3 level) of ASEAN-5 countries (values in USD thousand)

\begin{tabular}{cccccc}
\hline Products & 2001 & 2005 & 2008 & 2011 & 2014 \\
\hline $\begin{array}{c}\text { Maize (corn), Rice, Buckwheat, millet and canary seed, } \\
\text { Oats, Barley, Wheat, Rye }\end{array}$ & $2,284,596$ & $3,792,265$ & $9,299,798$ & $10,368,126$ & $7,612,219$ \\
$\begin{array}{c}\text { Coffee, Tea, Pepper, Capsicum, Cinnamon Flowers, Cloves, } \\
\text { Nutmeg, Seeds of Anise, Vanilla }\end{array}$ & $1,134,339$ & $1,855,369$ & $4,133,031$ & $5,571,648$ & $6,271,014$ \\
$\quad$ & & & & & \\
$\quad$ Apples & 769,709 & $1,433,095$ & $2,118,409$ & $3,182,877$ & $4,421,034$ \\
$\quad$ & & & & \\
$\quad$ Nuts, Citrus Fruits, Banana, Melons, Grapes, Apricots, & 418,882 & 551,644 & 875,153 & $1,740,488$ & $2,296,891$ \\
$\quad \begin{array}{l}\text { Manioc, Frozen Vegetables, Dried Vegetables } \\
\text { Starches; inulin,Flour and meal of vegetables, Wheat, Cereal } \\
\text { grain, Flour, Malt, Wheat Gluten }\end{array}$ & 282,426 & 486,612 & 942,243 & $1,897,144$ & $1,901,039$ \\
\hline
\end{tabular}

From the policy angle at regional level, ASEAN countries embarked on cooperation in the agriculture sector since 1968 (ASEAN Secretariat, 2015). The initial focus of cooperation was on food production and supply as food security was one of the most important agenda in the region at that point of time. This cooperation evolved ever since to include other areas of cooperation such as food handling, crops, livestock, fisheries, agricultural 
training and extension, forestry and joint cooperation in agriculture and forest products promotion scheme. Governed under the ASEAN Ministerial Meeting on Agriculture and Forestry (AMAF), the cooperation is active and gathers Agriculture Ministers from ASEAN countries annually to review and discuss cooperation initiatives that involves agriculture sector. The mandate that was given to this group was among others to facilitate and promote intra and extra ASEAN trade in agriculture and forestry products.

On the trade front, the ASEAN Roadmap for Integration of Agro-based Products guides the trade liberalization of the agriculture sector. The product coverage in the roadmap is both limited in number and value when it is compared to the range of agriculture products traded within ASEAN. The roadmap initially only covered some agricultural products such as peas and beans, certain seeds, tomatoes and related products, and vegetable oils. The measures identified in the roadmap to increase intra-ASEAN trade and investment are tariff elimination, non-tariff measures, customs cooperation, implementation of CEPT, rules of origin improvement, standards and conformance and logistics.

This study intends to investigate in detail, the nature of trade between the ASEAN-5 countries to understand how integrated are the trade of agriculture products and whether this integration has resulted in higher competition or countries complement each other in the agriculture sector. The level of competitiveness or complementarities between countries would reflect trade creation or trade diversion effect. By using Grubel-Lloyd's Intra-Industry Trade index and the Revealed Comparative Advantage (RCA), the study examines the effect of intra ASEAN trade in the agriculture industry by investigating 20 bilateral pair of countries across 13 product categories at HS3 level.

There are a few studies that have focused at industry level on the competitiveness and complementarities that have trade creating or trade diverting effect. One of such study investigated the relationship of the competitive or complementarities of ASEAN countries and China. In this study, Tan (2005) explored the impact of liberalization of trade in textile and clothings industry in China on ASEAN countries for the period of 1991 to 2003. The study found that ASEAN countries were more competitive than complementary in their relationship with China in this sector. With the use of a constant elasticity of substitution model, the study also found a significant negative effect of tariff elimination on ASEAN countries.

Pholphirul (2010) focused on Thailand by examining whether AFTA creates trade or actually diverts it away from the country. By using the Export Similarity Index (ESI), Intra-Industry Trade (IIT) Index, and Revealed ComparativeAdvantage (RCA) rank correlation, the study revealed a high degree of similarity regarding the trade structure between Thailand and AFTA, which indicates that there will be fewer trade-creation benefits from AFTA and a greater likelihood of trade diversion once the AFTA scheme has been fully implemented. This similarity pattern explains the reasons for future collaboration among member countries and supportive arguments for the future extension of ASEAN ("ASEAN+").

Chemsripong (2010) applied the Grubel Lloyd Index for the period between year 2000 and 2010 for intra ASEAN trade and observed that there was strong empirical support for the hypothesis that countries that have common borders and have eliminated or lowered barriers on trade with each other will have relatively high levels of intra-industry trade. Moreover, the extent of intra-industry trade will be positively correlated with trade intensity. The level of intra-industry trade is higher between Malaysia, Singapore and Indonesia compared to the rest of the world Thailand's IIT was increasingly changing from low-technology product to high-technology industries.

Ilyas, Mukhtar and Javed (2009) used year 1985 to 2005 as a reference period to analyze competitiveness among Asian rice exporters in the world rice market using the Balassa Revealed Comparative Advantage (BRCA) and White's Competitive Advantage (WRCA) over China in rice exports. There were no significant differences of revealed competitive advantage between Thailand and Vietnam or between India and Vietnam in agricultural product trade or Pakistan and Vietnam in total merchandise trade. Pakistan has a revealed comparative and competitive advantage in agricultural product trade (in rice) over all other countries and in total merchandise trade (in rice) over China, India and Thailand. Although Thailand and India are the two largest Asian exporters of rice with 47 per centof the market share in 2005 , on an average they did not have the greatest comparative and competitive advantage in rice exports. Pakistan has the greatest advantage in rice exports, Vietnam ranked second and Thailand ranked third in five major Asian exporters. Thus, it was concluded that both Pakistan and Vietnam could take the advantage of competitiveness and raise their share respectively in world rice market as compared with other Asian competitions.

Studies that specifically focus on intra-ASEAN agriculture trade are quite limited. One of the studies that examined agriculture trade in ASEAN was conducted by Diao, Roe and Somwaru (2001). The study investigated 
the cyclical trend of agriculture trade in ASEAN and revealed that ASEAN agriculture trade declined in the mid 1970s and throighout 1980s. The large part of the decline was due to the decrease in intra ASEAN trade. Kruger et. al (1991) found that agriculture products also face pricing policies in Asia. Some countries that control their exchange rate or overvalue the real exchange rate tend to hamper the exports of agriculture products owing to loss of comparative advantage in the world markets. Furthermore, similar issue is also faced by agriculture import. Policies by countries in ASEAN that prioritize domestic production contributed to trade policies that were biased against regional trade.

Whalley (2006) took a different approach by introducing the impact of eliminating trade restrictions under the Multi Fibre Arrangement (MFA) up to the end of 2004 for exports of clothing and textiles using data from US, EU, China and other main exporters. The result was only small impact on aggregate US and EU imports of clothing and textiles, and equally only small impact on aggregate Chinese exports of clothing and textiles. However, it was observed that there was a lot of changes in the countries pattern of trade, and also within more narrowly defined product categories. There were large increases in shipments from China to both the US and the EU and for the US proportionally more so in textiles than in clothing. But the US accounted for only 20 per cent of China's exports of clothing and textiles, and exports to Japan (comparable in size to the US) hardly changed, and exports to Hong Kong fell sharply. There were also large price falls for shipments to the US and to certain EU countries (Germany). The shares of other Asian suppliers in US markets generally stood still, with the largest falls occurring in preferentially treated non-Asian suppliers such as Mexico. In the EU markets, with the exception of India, all non-Chinese Asian suppliers experienced fall in their market share.

\section{Method}

The intra-regional trade effect in the agriculture sector for the ASEAN-5 countries are investigated by using Intra Industry Trade (IIT) and Revealed Comparative Advantage (RCA) indexes. The indexes are selected to analyze the competitiveness and complementarities between ASEAN-5 countries that would result in a greater understanding of the nature of intra-regional trade within ASEAN in the agriculture sector.

In general, IIT arises if a country simultaneously imports and exports similar types of goods or services. The classification of the goods or services in the same sector reflects the similarity nature of the goods or services. The concept of IIT first received attention in the 1960s in studies by Bela Balassa on the increased trade flows among European countries. Grubel and Lloyd (1975) then provided the definitive empirical study on the importance of intra-industry trade and how to measure it. Comprehensive theoretical foundations for explaining intra-industry trade came later in the 1980s and 1990s mostly based on a monopolistic competition framework.

IIT would reflect growth in intra-regional trade blocs and generate benefits from trade by increasing product variety. A country engaged in high levels of IIT for instance can concurrently reduce the number of products it produces and increase the variety of goods available to domestic consumers. In order to produce fewer variaties, a country can produce each variety of goods on a large scale with higher productivity and lower costs. Therefore, IIT tends to be apparent between countries that are similar in their factor endowment. Gains from trade will be large when economies of scale are strong and products are highly differentiated. This is very relevant to the agriculture sector in ASEAN where most ASEAN countries have similar factor endowment in the agriculture sector.

Both economies of scale and product differentiation are essential for the trade pattern of IIT. On economies of scale, it is specifically increasing returns to scale which often plays an important role for the appearance of IIT (Hansson, 1989). It is economies of scale in production, which makes each firm to produce only a specific set of varieties of the products within a product group. Economies of scale are the fundamental reason for IIT (Krugman, 1995). By trading, the countries will gain from having a larger market. In the case of constant returns to scale, the production is determined by comparative advantages, i.e. Heckscher-Ohlin theory.

In particular, this study uses the index introduced by Grubel and Lloyd (1975) that measure the level of intra industry trade. This measure, known as the Grubel-Lloyd index (GL Index), is intuitively appealing. Once a country's export and import value for a particular sector and period are known, it is calculated as:

$$
I I T i j=\frac{|X i j-M i j|}{X i j+M i j}
$$

Where;

$X_{i j}$ is the value of country i's exports of product $\mathrm{j}$ to the market under investigation

$M_{i j}$ is the value of the country's imports of product $\mathrm{j}$ from the market being examined 
When there is no intra-trade within a given industry, it is expected that a country either export or import it, not both, in which the IIT index would be equal to 0 . On the other hand, if a country's exports and imports within an industry were equal, the IIT index would be equal to 1. The IIT Index is calculated for the three separate industries in HS3 level classification to ensure that data are more accurate in representing product level items.

The second approach undertaken in this study is to investigate the RCA. The conventional thinking on FTA sets out that the potential gains from FTA depend on whether the trade pattern between one country and another in the FTA is complementary of substitutable. The purpose of RCA index is to measure the competitiveness of the countries' industries in the global market. RCA index is a standard approach or methodology to estimate a country's comparative advantage or comparative disadvantage in commodities, industries or sectors. Based on Ricardian theory, comparative advantage occurs due to technological dissimilarities across nations, while the Hecksher-Ohlin (H-O) theory considers cost dissimilarities arising due to differences in factor prices across nations, assuming constant technology. In this regard, it can be summarized that trade theories in classical context are based on pre-trade relative price differences across countries.

According to Balassa (1965), it is not necessary to observe all elements effecting comparative advantage of any country rather one should observe patterns of trade. Since data on trade explains revealed comparative advantage, it is a commonly accepted measure. Balassa Index focuses on estimating comparative advantage of any country and not on determining its sources. The revealed comparative advantage (RCA) index, introduced by Balassa (1965), is used to determine the products in which a country has a comparative advantage. It is defined as the ratio of a country's share of the commodity in the country's total exports to the share of world exports of the commodity in total world exports. A country is said to have a revealed comparative advantage if the value of the index exceeds 1 and a revealed comparative disadvantage if the index's value is below 1 . The larger the difference between countries' RCA indices, the more suitable they are as FTA partners.

This study uses the revealed comparative advantage (RCA) index, introduced by Balassa (1965), which determines the comparative advantage of a product for a country. It is defined as the ratio of a country's share of the commodity in the country's total exports to the share of world exports of the commodity in total world exports. A country is said to have a revealed comparative advantage if the value of the index exceeds 1 and a revealed comparative disadvantage if the index's value is below 1 . The larger the difference between countries' RCA indices, the more suitable they are as FTA partners.

In general the results of this index would assume that if the index is above 1, the country has comparative advantage and when the index is below 1, the country has comparative disadvantage. To ensure that this model fits for the purpose of intra-ASEAN trade, this study employs a formula based on the basic RCA formula above. This formula is to show to what extent members of ASEAN are competing in the ASEAN market and it will also show the degree of competitiveness of each ASEAN country in selected ASEAN markets for the agriculture sector. The formula is as follows:

Where;

$$
R C A_{i j}=\left(X_{i j m} / X_{i t m}\right) /\left(X_{a w j} / X_{a w t}\right)
$$

$X_{i j m}$ is exports of product $\mathrm{j}$ by country $\mathrm{i}$ to market under investigation;

$X_{i t m}$ is total exports of country $i$ to market under investigation;

$X_{a w j}$ represents ASEAN's exports of product $\mathrm{j}$ to the world;

$X_{\text {awt }}$ represents total ASEAN's exports to the world

For the purpose of both IIT and RCA indexes, data is collected from published materials by International Trade Centre based in Geneva, which collects data from UNCOMTRADE (International Trade Centre, 2015). The data that is collected is for the ASEAN-5 countries for year 2001 to 2014. The types of data include individual ASEAN-5 values for exports and imports to and from individual ASEAN-5 countries. The data is collected at HS4 level and it is then combined to form the HS3 level data to provide more accurate results. Exports of each individual ASEAN-5 to the world is also collected using the same source.

Next, to investigate the relationship at intra-ASEAN level, both indexes are estimated for five ASEAN countries, namely, Indonesia, Malaysia, Thailand, Philippines and Vietnam. These countries are chosen based on the involvement in AFTA and unlike many other studies that include Brunei and Singapore, Vietnam is chosen to replace these countries. Brunei is excluded as the trade value for all the products are very low and inclusion of Singapore as a free trade port would distort the actual benefit of AFTA as it would not represent the benefit of AFTA. 


\section{Results}

\subsection{Intra-Industry Trade by Country}

a) Indonesia

The ASEAN-Indonesia IIT values were generally far from unity. IIT for Malaysia-Indonesia was the highest with a value of 0.442 while Vietnam-Indonesia about 0.205 , Philippines-Indonesia about 0.132 and Thailand-Indonesia about 0.233. Malaysia-Indonesia IIT is shown in Table 4. The IIT value for Malaysia-Indonesia recorded a high value for HS071 with an average of 0.829. Although there is no obvious trend of the IIT from year 2001 to 2014, some of the years recorded value close to unity. Malaysia-Indonesia IIT recorded high value for product HS070 with 0.717 . This product category also indicated values close to unity, however the values were not maintained throughout the period. Product of HSO80 on the other hand recorded a decreasing trend from 2001 to 2014. IIT value for Indonesia-Thailand as shown in Table 5, did not record significant IIT although some years showed an increasing and decreasing trend. Product of HS071 and HS120 showed an increasing trend while product of HSO70 and HS121 recorded a decreasing trend.

IIT for Philippines-Indonesia showed a very weak trend for all product categories as shown in Table 6. Product of HS081 for example did not even record a single intra industry trade between Philippines and Indonesia. Similarly, as shown in Table 7, Vietnam-Indonesia aslo recorded a low value. The only quite significant intra-industry trade was for product HS090 that recorded an average 0.538 . This product approached unity value in year 2009, which was 0.987, but the value dropped in years after 2009 .

\section{b) Malaysia}

For Malaysia, the average IIT values with ASEAN countries recorded was quite low. Malaysia-Indonesia recorded the highest IIT of about 0.442 while the IIT value for Malaysia-Vietnam about 0.143 , Malaysia-Philippines about 0.183 and Malaysia-Thailand about 0.392 .

IIT for Malaysia-Indonesia recorded high value for product HS071 with 0.829. IIT for some years recoded value close to unity as shown in Table 8. Product HS070 also recorded a high average value of 0.717 and two years recording close to unity value.

IIT for Malaysia-Thailand recorded high value of IIT for product HS070 with 0.768 which fluctuated during the whole period of investigation. As shown in Table 9, product of HS080, HS121, and HS140 all recorded a decline from year 2001 to 2014.

As for the Malaysia-Philippines and Malaysia-Vietnam IIT as shown in Table 10 and Table 11, there were no significant values of IIT, as the values remained low in almost all categories.

\section{c) Philippines}

The IIT value of ASEAN countries-Philippines recorded generally very low values. The IIT of Thailand-Philippines recorded an average value of about 0.261 , while the IIT value for Malaysia-Philippines was about 0.183 and Vietnam-Philippines was about 0.110 .

IIT value between these four countries and Philippines did not record any significant value. As shown in the following tables, Table 12, Table 13, Table 14 and Table 15, only IIT for Thailand-Philippines for products of HS080 and HS120 recorded significant value with some years recording values close to unity.

\section{d) Thailand}

The IIT values for ASEAN countries against Thailand on average were below unity. Malaysia-Thailand IIT value recorded an average value of 0.392 while Vietnam-Thailand value at 0.349 , Philippines-Thailand about 0.261 and Indonesia-Thailand about 0.233. As shown in Table16, IIT index for Malaysia-Thailand is quite high in HS070 with an average of 0.768 . The trend from year 2001 to 2014 also shows a fluctuating trend although for some years it recorded values close to unity. There were also few other products that randomly had values close to unity in some years although no definitive pattern was observed.

Table 17 shows IIT for Indonesia-Thailand. From the table, IIT values were quite low for all categories of product. The highest value was recorded for product HS120 with 0.446 on average. Product of HS120 also shows an increasing trend from year 2001 to 2014 and in year 2014 the value was close to unity. For Philippines-Thailand, as shown in Table 18, product of HS120 recorded an average value of 0.772 with some years the values approaching to unity. Product of HS130 and HS080 both showed a decreasing trend and the IIT value for Philippines-Thailand for those products declined until 2014.

Table 19 shows the IIT values for Vietnam-Thailand, which also did not show an outstanding picture. Although 
there were some trends increasing or decreasing for certain product categories, the trend was inconsistent.

e) Vietnam

IIT of ASEAN-Vietnam for the agriculture industry recorded a low average value. The IIT for Vietnam-Thailand recorded an average value of 0.349 , while the IIT value for Vietnam-Malaysia recorded an average of 0.143 . IIT for Vietnam-Indonesia recorded 0.205 and IIT value of Vietnam-Philippines recorded 0.110. As shown in Tables 20, 21, 22 and 23, it can be observed that only very few product categories recorded IIT value close to unity. This values were however very random and did not show any significant trend.

\subsection{Summary of Intra Industry Trade}

The IIT values by country show that the level of IIT between countries in ASEAN for the agriculture sector is very low and limited. As shown in Table 24, only Malaysia, Thailand and Indonesia recorded significant IIT values. This shows that intra industry trade between ASEAN countries was very low and limited. It also suggests that ASEAN countries were more focused on inter industry trade instead. This is understandable as most of the agriculture products do not go through advanced processing. The nature of the production for agriculture products consists of relatively simple transformation of raw materials with which the ASEAN countries are endowed. This transformation usually is not suited to division across the economies in ASEAN.

\subsection{Revealed Comparative Advantage by country}

\section{a) Indonesia}

All four ASEAN countries recorded significant comparative advantage in the Indonesian market for all product categories. The RCA index of Vietnam-Indonesia recorded the highest value with an average of 4.202, and then followed by Philippines-Indonesia with RCA index of 1.490 while Thailand-Indonesia recorded RCA index of 1.431 and Indonesia-Malaysia with RCA index of 1.054.

The RCA index for Thailand-Indonesia as shown in Table 25 is concentrated in 5 product categories for the period of 2001-2014. The average RCA index for product of HS110 -Starches; inulin, Flour and meal of vegetables, Wheat, Cereal grain, Flour, Malt, Wheat Gluten recorded significant RCA index with 6.530 followed by RCA index for product of HS081-Dried Fruits, Frozen Fruits, Preserved Fruits, Citrus Fruits and Melon Peel with 5.577, HS100-Maize (corn), Rice, Buckwheat, millet and canary seed, Oats, Barley, Wheat, Rye with 2.554, HS120 -Ground Nuts, Seeds, Oil Seeds, Soya Beans etc with 1.727 and HS070-Cabbages, Cauliflowers, Vegetables, Potatoes. Lettuce, Carrots, Turnips with 1.583.

The recorded RCA index values above did not show a consistent trend and the values fluctuated during the period of investigation. Product of HS081 showed an unrecovered declining trend from year 2009 onwards when the RCA index dropped from 5.828 in 2009 and reduced to 2.899 in 2014. Similar trend was also shown for product of HS100 when the RCA index dropped in 2004, from 5.882 in year 2003 to 1.828 in year 2004. It even touched onto losing its competitiveness in year 2005 recording only 0.712 and years after that, it remained in the range of 0.460 to 2.700. Product of HS120 also recorded a declining trend and since year 2010, Thailand loss its comparative advantage in the Indonesian market for this product category. The only category that shows an increasing trend is product of HS070, which gained its competiveness in year 2005 and thereafter showed a stable value until year 2014.

The RCA index of Philippines-Indonesia in the agriculture industry is shown in Table 26. The average RCA index for the period 2001-2014 of 9.879 was recorded for product of HS070-Cabbages, Cauliflowers, Vegetables, Potatoes. Lettuce, Carrots, Turnips. The values faced some rise and fall throughout the period, however, it showed a declining trend since year 2011 where the RCA index fell from 13.543 to 2.397 in 2014. This is then followed by product of HS130-Vegetable saps \& extracts, Lac; natural gums, resins, gum-resins \& balsams which recorded RCA index of 4.624. Product of HS121-Locust Beans, Medicinal Plants, Swede, Mangolde etc. recorded an average RCA index of 3.783, which did not show significant RCA index throughout the period of 2001-2014.

As shown in Table 27, Malaysia-Indonesia RCA index on average was significant for product of HS120-Ground Nuts, Seeds, Oil Seeds, Soya Beans etc. with 6.188, followed by product of HS070-Cabbages, Cauliflowers, Vegetables, Potatoes. Lettuce, Carrots, Turnips with 3.886 and product of HS140-Vegetable Products and Materials with 1.090. HS070 and HS120 both showed values that were consistent for the whole period of investigation. Product of HS140 only remained competitive for a short period of time, which is from 2009 to 2011.

The RCA index of Vietnam-Indonesia in the agriculture industry is shown in Table 28 below. Product of 
HS120-Ground Nuts, Seeds, Oil Seeds, Soya Beans etc. recorded highly significant RCA index of 23.929. The competitiveness recorded was only attributed for the period from 2001 to 2010. From year 2011 onwards, the RCA index of Vietnam-Indonesia plunged downwards and loss its competitiveness for this product category. Product of HS100- Maize (corn), Rice, Buckwheat, millet and canary seed, Oats, Barley, Wheat, Rye recorded an average RCA index of 15.574 with huge fluctuations during the period of investigation. It was however observed that despite the fluctuations, Vietnam was still competitive in the Indonesia agriculture industry for the whole period of investigation except for year 2009, when the RCA index recorded showed a loss in competitiveness. Similar trend was also revealed for product of HS070- Cabbages, Cauliflowers, Vegetables, Potatoes, Lettuce, Carrots, Turnips which recorded an average RCA index of 8.408. The exception however was in year 2007, when Vietnam loss its competitiveness for this product category. Product of HS090-Coffee, Tea, Pepper , Capsicum, Cinnamon Flowers, Cloves, Nutmeg, Seeds of Anise, Vanilla recorded an average RCA index of 2.668 with values that remained stable throughout the period of investigation. Product of HS081-Coffee, Tea, Pepper, Capsicum, Cinnamon Flowers, Cloves, Nutmeg, Seeds of Anise, Vanilla recorded RCA index of 1.111 on average and showed an increasing trend especially from year 2007 onwards when the values turned from uncompetitive to competitive in 2007 and remained stable up to year 2013.

\section{b) Malaysia}

For all HS3 products of agriculture for 2001-2014, RCA index for Vietnam-Malaysia showed an average of about 2.211, which is the highest, compared to other countries. Then, it is followed by Indonesia-Malaysia, with an average index of about 1.167. The other two countries, Thailand and Philippines showed an average value of RCA below 1, which were 0.790 and 0.304 respectively. However, this aggregate value does not represent each product under the HS3 that actually gives clearer picture of competiveness of each product in the agriculture industry in the case of Malaysia.

Table 29 shows Thailand-Malaysia RCA index. From the table, it can be observed that Thailand is the most competitive with highest RCA in product of HS110 - Starches; inulin,Flour and meal of vegetables, Wheat, Cereal grain, Flour, Malt, Wheat Gluten where the value was 3.729 followed by product of HS120 - Ground Nuts, Seeds, Oil Seeds, Soya Beans etc. with a value of 2.051. The other two products that recorded significant RCA were HS100 - Maize (corn), Rice, Buckwheat, millet and canary seed, Oats, Barley, Wheat, Rye with RCA value of 1.803 and product of HS070 - Cabbages, Cauliflowers, Vegetables, Potatoes. Lettuce, Carrots, Turnips with RCA value of 1.494. The RCA index for these four product categories remained consistent throughout the observation periods although the RCA values fluctuated in certain years. However, product of HS110 and HS100 both show a declining trend.

Next, Table 30 presents Indonesia-Malaysia RCA index. The table shows that Indonesia has significant competitive advantage in 5 product classifications. The highest RCA index for Indonesia-Malaysia was recorded for product of HS120 - Ground Nuts, Seeds, Oil Seeds, Soya Beans etc. with an average of 4.702, followed by product of HS091 - Ginger,saffron,turmeric, thyme, bay leaves \& curry with RCA value of 2.706, product of HS070 - Cabbages, Cauliflowers, Vegetables, Potatoes. Lettuce, Carrots, Turnips with RCA value of 2.456, product of HS140 - Vegetable Products and Materials with RCA value of 1.269 and product of HS090 - Coffee, Tea, Pepper, Capsicum, Cinnamon Flowers, Cloves, Nutmeg, Seeds of Anise, Vanilla with RCA value of 1.053. RCA index for product of HS120 and HS070 both recorded significantly high average values, but both products showed a declining trend. RCA index for product of HS120 fell from 6.051 in year 2001 to 1.089 in 2014 whereas RCA index for product of HS 070 loss its competitiveness in 2010 and in 2014 the value recorded a low level of competitiveness with the RCA index recording 0.500. The other 3 product sectors remain indifferent although with some minimal fluctuations during the investigated periods.

The RCA index for Philippines-Malaysia is shown in Table 31. Based on the table, only one product, HS130Vegetable saps \& extracts, Lac; natural gums, resins, gum-resins \& balsams has a competitive advantage in Malaysian agriculture industry, where the RCA index was 1.237. However, the product has shown rapid increase in competitiveness in Malaysia's agriculture market from year 2011 onwards. Other products as shown in the table recorded a less significant competitiveness in the Malaysian agriculture industry.

RCA index for Vietnam-Malaysia is shown in Table 32. On average, Vietnam had a significant advantage in product of HS120 - Ground Nuts, Seeds, Oil Seeds, Soya Beans etc. where the value recorded was 10.691, followed by HS100 - Maize (corn), Rice, Buckwheat, millet and canary seed, Oats, Barley, Wheat, Rye with RCA index of 9.248. Other products that recorded positive RCA index were HS090 at 2.295, HS 070 at 1.962, HS110 at 1.414 and HS121 at 1.108. Of these competitive RCA index, HS120 and HS100 showed ecreasing trend of RCA from year 2001 to 2013. In the case of product HS121, the product recorded a decreasing trend and 
eventually after 2008 , Vietnam, has lost its competitiveness in this category of product. RCA index for product of HS090 has been rather stable from 2001 to 2014 although there were slight fluctuations recorded. RCA index for product of $\mathrm{HSO70}$ has showed remarkable increase in trend from the product being incompetitive in Malaysia agriculture industry in 2008 , which was then turned in an upward trend recording a competitive RCA index with 6.304 in 2013.

\section{c) Philippines}

The RCA index recorded was on average significant for Vietnam-Philippines with 3.799 followed by Vietnam-Indonesia with 1.652 for the period 2001-2014. The RCA index for Thailand-Philippines and Malaysia-Philippines recorded an average of 0.589 and 0.088 respectively.

This average RCA index, however, was quite different at each product category. The RCA index for Thailand-Philippines on average recorded significant values for product of HS100 - Maize (corn), Rice, Buckwheat, millet and canary seed, Oats, Barley, Wheat, Rye with 2.500 and HS110- Starches; inulin,Flour and meal of vegetables, Wheat, Cereal grain, Flour, Malt, Wheat Gluten with 2.757. Although both product categories showed rise and fall in value, the values remained stable throughout the period investigated. The RCA index for Malaysia-Philippines on the other hand, as described in Table 33, did not show any significant RCA value for all product categories.

The RCA index for Indonesia-Philippines is shown in Table 34. The RCA index was significant for products of HS121- Locust Beans, Medicinal Plants, Swede, Mangolde etc.where the index recorded was10.812, followed by HS120- Ground Nuts, Seeds, Oil Seeds, Soya Beans etc. with 6.780 and HS071- Manioc, Frozen Vegetables, Dried Vegetables with 1.239. The RCA index of HS121 and HS120 remained strong and stable for the whole period of investigation while HS071 loss its competitiveness in 2010 and regaining competitiveness only in 2014.

The RCA index for Vietnam-Philippines was significant for product of HS100- Maize (corn), Rice, Buckwheat, millet and canary seed, Oats, Barley, Wheat, Rye with an average of 29.886 as shown in Table 35. Although the values fluctuated for the period under investigation, the value remained double digits. Product of HS120- Ground Nuts, Seeds, Oil Seeds, Soya Beans etc. recorded an average of 8.021 although the value showed a sharp downfall from having a significant double digit RCA value to insignificant value since 2006 onwards. The RCA values did not regain significance up to 2014. Product of HS110 and HS090 both with an average RCA index of 4.849 and 4.370 recorded a stable and strong value throughout the period of investigation.

\section{d) Thailand}

On average, for all product categories under the agriculture industry for the period of 2001 to 2014, the RCA value was recorded significant only for Vietnam-Thailand where the average value recorded was 3.058. Other average RCA values that recorded insignificant average values were Philippines-Thailand where the value was 0.872 , Indonesia-Thailand recorded 0.715 and Malaysia-Thailand with a value of 0.431 .

Despite an overall average insignificant value, the RCA index of Malaysia-Thailand recorded an average significant value for 2 product categories as shown in Table 36. Product of HS140- Vegetable Products and Materials recorded an average RCA index of 2.059 with a substantial shift from insignificant RCA value up to year 2007 to a stable significant value from year 2008 onwards. The RCA index for Malaysia-Thailand was also significant for product of HS070-Cabbages, Cauliflowers, Vegetables, Potatoes. Lettuce, Carrots, Turnips with an average value of 1.632 .

Indonesia exhibited 3 product categories with significant RCA index as shown in Table 37. The RCA index for product of HS140-Vegetable Products and showed an increasing trend from year 2006 to 2014 with an average of 3.948. This is followed by the RCA index for product of HS091- Ginger, saffron, turmeric, thyme, bay leaves $\&$ curry which recorded an average of 2.085 . However, the RCA index for this product category has shown a decreasing trend. From year 2001 to 2005, the RCA index for product of HS091 was significant and from year 2006 to 2014, the RCA index fell to become insignificant and the values decreased rapidly. As for product of HS120- Ground Nuts, Seeds, Oil Seeds, Soya Beans etc, the RCA index for Indonesia -Thailand recorded an average of 1.097 .

As shown in Table 38, the RCA index for Philippines-Thailand recorded an average of 4.459 for HS121-Locust Beans, Medicinal Plants, Swede, Mangolde etc.. Although it was a significant value, the trend shows rise and fall in the value throughout the period of investigation. Since year 2013, the RCA index of Philippines-Thailand for product of HS121 became insignificant. Prodcut of HS130-Vegetable saps \& extracts, Lac; natural gums, resins, gum-resins \& balsams recorded an average of 4.053 with stable and significant values throughout the whole 
period while showing an increasing trend for the period 2012 to 2014. Product of HS110 and HS120 recorded RCA index of 1.068 and 1.311 respectively, however the trend shown by both product category were inconsistent where for some of the years.

The RCA index of Vietnam-Thailand for the agriculture industry is shown in Table 39. It points out the high RCA index for HS120-Ground Nuts, Seeds, Oil Seeds, Soya Beans etc. with an average of 29.649. The trend however is showing a decline, which started off with RCA index with double-digit values in year 2001 to 2010 and declined to single digit for year 2011 onwards. Product of HS081-Dried Fruits, Frozen Fruits, Preserved Fruits, Citrus Fruits and Melon Peel recorded RCA index with an average of 2.784, product of HS110- Starches; inulin,Flour and meal of vegetables, Wheat, Cereal grain, Flour, Malt, Wheat Gluten with an average of 1.840, product of HS080-Nuts, Citrus Fruits, Banana, Melons, Grapes, Apricots, Apples with 1.738, product of HS140 with an average of 1.180 and product of HS090 with 1.027.

\section{e) Vietnam}

The average RCA index of Indonesia-Vietnam was the only pair that recorded a significant value with 1.763 . The RCA index of Thailand-Vietnam recorded 0.902, while the RCA index for Philippines-Vietnam recorded 0.510 and Malaysia-Vietnam recorded 0.235 .

As shown in Table 41, the RCA index of Thailand-Vietnam showed a significant value for product of HS120Dried Fruits, Frozen Fruits, Preserved Fruits, Citrus Fruits and Melon Peel with an average of 5.279 and product of HS081-Dried Fruits, Frozen Fruits, Preserved Fruits, Citrus Fruits and Melon Peel recorded an average value of 2.938. The RCA index for product of HS120 remained consistent during the whole period of investigation and product of HS081 has shown an increasing trend in year 2009 onwards with significant RCA index values.

The only significant RCA index recorded for Malaysia-Vietnam was for product of HS120-Ground Nuts, Seeds, Oil Seeds, Soya Beans etc which recorded 1.436 on average and showed an increasing trend from year 2006 onwards as shown in Table 42. The RCA index of Philippines-Vietnam in the agriculture industry is shown in Table 43. The RCA index for Philippines-Vietnam recorded significant RCA value for product of HS130-Vegetable saps \& extracts, Lac; natural gums, resins, gum-resins \& balsams with 3.283. Since year 2005, the RCA index for Philippines-Vietnam gained significant values for this product category and the trend recorded was increasing and in 2014, the value recorded was 16.404. The RCA index for Philippines-Vietnam also recorded significant value for product of HS121 with an average of 1.719 .

Table 44 shows the RCA index of Indonesia-Vietnam in the agriculture industry. There were 7 product categories that recorded significant RCA values. Product of HS121 recorded RCA index of 5.726, followed by product of HS091 with RCA index of 4.923, product of HS080 with RCA index of 4.290, product of HS090 with RCA index of 3.232, product of HS130 with RCA index of 1.279, product of HS121 with RCA index of 1.105 and product of HS140 with RCA index of 1.045. The RCA Index of Indonesia-Vietnam in the agriculture industry recorded significant values for most product categories and only six product categories did not record significant values.

\subsection{Summary of Revealed Comparative Advantage}

Although Malaysia has shown significant RCA values for four product categories as shown in Table 45 below, for all the product categories, Malaysia faces steep competition with ASEAN countries. The manner of such competition does not suggest that Malaysia has total comparative advantage despite recording significant RCA values.

Thailand, despite recording significant RCA values for many product categories, most products showed that it was competing with other ASEAN countries (Table 46). Thailand's RCA index without such competition is only for HS110 and HS081.

Indonesia also recorded many product categories with significant RCA values, some of which were competing with other ASEAN countries. However, Indonesia recorded the highest number of product categories with sole significant RCA within ASEAN. The product categories were mostly apparent for the pairs between Indonesia and Vietnam as shown in Table 47.

Philippines similar to Malaysia recorded significant RCA values only for a few items, all of which were in competition with other ASEAN countries. It also must be noted that Philippines and Malaysia do not have any significant RCA values for each other, suggesting that both countries do not have any advantage in terms of AFTA for the agriculture sector. Vietnam recorded many product categories with significant RCA values. Most of them were in competition with Thailand and Indonesia. Vietnam's sole competitive RCA value was recorded for HS090 and HS121. 
In conclusion, it can be summarized that for the agriculture sector in ASEAN, the intra industry trade is quite limited due to most of the products are upstream products and the economies do not offer product differentiation. The RCA value on the other hand was quite forthcoming. Thailand, Indonesia and Vietnam in general have shown intense competition with each other in the agriculture sector. The trend recorded also proved that Vietnam has in certain products competed with other ASEAN countries and caused other countries to lose their competitiveness. Thailand despite being one of the largest agriculture exporter in the world might have concentrated its market outside ASEAN, causing Vietnam to take advantage in terms of competitiveness in ASEAN.

The level of RCA among these countries actually suggests that AFTA might have only assisted some countries to integrate within ASEAN. The competition among Thailand, Indonesia and Vietnam coupled with the limited level of IIT values further suggests that integration efforts under AFTA for the agriculture sector has created competition but it has not helped countries to specialize in particular products.

\subsection{Overall Summary}

\section{a) RCA and IIT in the Malaysian Market}

The IIT values for ASEAN countries in the Malaysian agriculture market was recorded high only for product of HS070, HS071 with Indonesia and product of HS070 with Thailand. Similarly, product of HS070 also recorded significant RCA values for both Indonesia and Thailand. This however was not the case for product of HS071 where Indonesia did not record significant RCA value in Malaysia's market suggesting a one-way trade. The RCA values of Thailand and Indonesia dominated Malaysia's agriculture industry with Thailand recording high RCA values for product of HS100, HS110 and HS120. Indonesia's position in product of HS090, HS091, HS120 and HS140 was considerably competitive. Except for product of HS070 and HS120, Thailand and Indonesia were not competing with each other for the same product categories. This however changed when Vietnam is included in the comparison. Vietnam recorded high RCA values for the entire product categories mentioned above, which suggests that Vietnam is competing with both Thailand and Indonesia in all the products that they have significant RCA values. Vietnam's RCA values are also not matched with the IIT values that suggest that most products were one-way trade. Product of HS100 and HS120 recorded considerably high RCA values for Vietnam that showed a declining trend similar to the decline by Thailand. This might be due to the change in export concentration during this period of time.

In general, the trend and values of IIT and RCA in the Malaysian agriculture market shows some degree of competition between Indonesia, Vietnam and Thailand particularly in HS070 and HS120. The results also suggest that most products were one-way trade as IIT values were only significant for very few products.

\section{b) RCA and IIT in the Thailand Market}

The IIT values for ASEAN countries in Thailand's agriculture market only recorded significant values for product of HSO70 with Malaysia and product of HS120 with Indonesia. The RCA values for ASEAN countries in Thailand's agriculture industry recorded a steep competition between Indonesia, Philippines and Vietnam for product of HS120. Vietnam's RCA values for product of HS120 severely dropped, while Indonesia recorded an increasing trend for its RCA values for product of HS120. Philippines on the other hand recorded fluctuating values for product of HS120 due to the intense competition among ASEAN countries.

Other product categories recorded significant RCA values as well for ASEAN countries although there was no intense competition between ASEAN countries. Product of HS140 recorded an increasing RCA trend for both Indonesia and Malaysia. Indonesia recorded a significant decrease in RCA value for product of HS091 although other ASEAN countries did not show any significant trend for product of HS091.

ASEAN countries' IIT and RCA values did not show any close links in Thailand's agriculture market. However, it was observed that there was intense competition between ASEAN countries for product of HS120.

\section{c) RCA and IIT in the Indonesian Market}

The IIT values of ASEAN countries in Indonesian agriculture market was only prevalent for product of HS071, HS070 and HS120 with Malaysia. Other countries did not show significant levels of IIT values, suggesting one-way trade between most the pairs investigated. Being the largest consumer market for agriculture industry in ASEAN, the RCA values present interesting values. All four ASEAN countries investigated showed a positive RCA value for product of HS070. Thailand in general has shown a slowly increasing trend, while Vietnam has shown extreme increase in RCA values especially since year 2009. Malaysia and Philippines both recorded fluctuating values. The trend shows that all four ASEAN countries are competing against each other for their market share in Indonesia. It also shows that Vietnam possesses higher RCA values after 2009 that might have 
affected Malaysia and Philippines position for product of HS070.

Vietnam also showed very high value for product of HS100, although the trend seemed to fluctuate. This is more evident as Thailand's position for product of HS100 depleted badly since 2004, which suggest that the intense competition between Vietnam and Thailand for product of HS100 somehow shows that Vietnam has gained better position in Indonesia.

Similar trend was also observed in product of HS081. Thailand's RCA value declined badly since 2004 and Vietnam gained competitive values since 2002 and the trend increased rapidly. Vietnam's competitiveness in product of HS081 resulted in Thailand losing its competitiveness.

The level of competition among ASEAN countries for the similar products in Indonesia has shown that Vietnam has mostly competed against other countries within ASEAN and managed to position itself in a more competitive level in the Indonesia agriculture market.

\section{d) RCA and IIT in the Philippines Market}

The IIT values for ASEAN countries in the Philippines market did not show any significant value except for product of HS120 with Thailand, which recorded a fluctuating trend for the years under investigation. This shows that most of ASEAN's trade with Philippines was focused in one-way trade.

An interesting trend was observed for RCA values of product HS120. Indonesia recorded rapid increase in competitiveness for product of HS120, while Vietnam loss its competitive value since year 2007. The trend shows that both country competed in the same product category and Indonesia has emerged more competitive than Vietnam in product of HS120.

Besides product of HS120, product of HS100 recorded significant RCA values for Thailand and Vietnam. Indonesia recorded a high product of HS121 RCA value, while Vietnam managed to remain competitive in product of HS090 and HS110 throughout the period of investigation.

Malaysia did not show any significant RCA and IIT values in the Philippines agriculture market. The other three ASEAN countries all showed some levels of competitiveness in different products although competition was apparent between Indonesia and Vietnam for some of the products.

\section{e) RCA and IIT in the Vietnamese Market}

The IIT value that was significant in Vietnam's agriculture market was for product of HS090 with Indonesia. Product of HS090 also recorded an increasing RCA value which shows that intra industry trade is observed for this product category. Malaysia, Thailand and Indonesia recorded significant RCA values for product of HS120. In terms of trend, the three countries compete with each other causing Indonesia's RCA value to decrease and Malaysia's RCA value rose steadily throughout the period of investigation. Thailand's RCA value remained significant although it fluctuated during the whole period. Thailand however showed an increasing trend for its RCA value for product of HS081. Both Philippines and Indonesia also recorded an increasing trend for product of HS130 and HS121. Indonesia recorded the highest number of products with significant RCA values, recording significant values also in product of HS080 and HS091. The number of products with significant RCA values covered by Indonesia is quite interesting, as similarly, many Vietnamese products also gained significant RCA values in the Indonesian agriculture market.

\section{Conclusion}

The results of both IIT and RCA show differing trends across different product categories. By identifying the most significant product categories for the agriculture industry that is represented by some important trends, it gives a better understanding on how ASEAN countries have integrated in the agriculture industry. The following product categories with most significant RCA and IIT values are product of HS070, HS090, HS100, HS110 and HS120.

\subsection{Product of HSO70 - Cabbages, Cauliflowers, Vegetables, Potatoes. Lettuce, Carrots, Turnips}

All ASEAN-5 countries recorded significant RCA values for the product of HS070. The main export destination is Indonesia and Malaysia. Indonesia sources product of HS070 from all ASEAN countries, thus creating a high degree of competition between the ASEAN countries. For the export destination of Indonesia, there is a steep competition between Vietnam and Philippines, while Malaysia also recorded trend showing that the RCA values were increasing. There was also competition between Thailand, Indonesia and Vietnam when exporting to Malaysia These pairs also showed a significant value of IIT for product of HS070 except for the pairs of Philippines-Indonesia and Vietnam-Indonesia. 
It can be summarized that for product of HS070, there exist a positive level of integration between ASEAN-5 countries given both high RCA and IIT values. This is with the exception of the steep competition between Philippines and Vietnam in the Indonesian market. In the earlier years, 2001-2007, Vietnam recorded very high RCA values with Indonesia, however, the value dropped from 2008 onwards given the competition from Philippines.

4.2 Product of HSO9O - Coffee, Tea, Pepper, Capsicum, Cinnamon Flowers, Cloves, Nutmeg, Seeds of Anise, Vanilla

All the ASEAN-5 countries are importer of product of HS090, which mainly consist of coffee and tea products. Indonesia and Vietnam are both competitive in their export destinations, which is not concentrated in certain markets only. Indonesia and Vietnam also recorded significant IIT values showing that there exist two way trade between both these countries. The product of HS090 shows that significant RCA recorded between pair countries complement each other rather than compete with each other.

\subsection{Product of HS100 - Maize (Corn), Rice, Buckwheat, Millet and Canary Seed, Oats, Barley, Wheat, Rye}

Product of HS100 which consist mainly of Rice, the main export of ASEAN in agriculture, showed that there has been steep competition between Thailand and Vietnam for the same markets. From the trend, it can be observed that Thailand's RCA value was reducing, while Vietnam's RCA value showed an increasing trend. This suggest that Vietnam has started to take over Thailand's export market in the same countries. This also means that the high degree of competition between Thailand and Vietnam has resulted in Thailand losing its competitiveness in some ASEAN countries.

\subsection{Product of HS110 - Starches; Inulin,Flour and Meal of Vegetables, Wheat, Cereal Grain, Flour, Malt, Wheat Gluten}

Similar to the exports of rice or Product of HS100, Thailand and Vietnam compete with each other for product of HS110 in the Malaysia and Philippines markets. Thailand however is the only country with significant RCA value in Indonesia. The trend for product of HS110 shows that, despite some competition from Vietnam for product of HS110 especially in the Philippines, where Vietnam's RCA value surpassed Thailand's value, Thailand still remains competitive in larger markets when the market value is combined for Malaysia, Indonesia and Philippines. Although there is some degree of competition between Vietnam and Thailand for this product category, Thailand remains more competitive.

\subsection{Product of HS120 - Ground Nuts, Seeds, Oil Seeds, Soya Beans etc.}

The RCA values for the product of HS120 were significant for all ASEAN-5 countries. The destination of export is also represented by all countries and this largest pair of countries with significant RCA values shows that product of HS120 is most integrated in ASEAN for the agriculture industry. Malaysia for example recorded significant RCA value for the markets of Indonesia and Vietnam, while Thailand recorded significant RCA for Indonesia, Malaysia and Vietnam markets. Indonesia and Vietnam on the other hand recorded highly significant values with nearly all other countries.

In terms of trend, there were significant movement of RCA value in each market. For Malaysia as the export destination, the RCA values were reducing in trend from both Vietnam and Indonesia. The reduction in RCA values for Malaysia also suggest that Malaysia is less dependent on the imports from Vietnam and Indonesia as the imports from Thailand and local supply might have taken over the need for importing. Similar trend was also shown for the Indonesian market. After year 2011, the highest RCA value which was from Vietnam loss its significance and Vietnam was not penetrating the Indonesia market anymore after 2011.

In terms of the Thailand market, although initially Vietnam recorded very high RCA values, the values started to drop dramatically after year 2008. This was also similarly relevant for the Philippines market. The issue of Vietnam losing its competitiveness in all of its market although still recording significant value only in Thailand, coupled with the fact that other countries also recording significant RCA values shows that the competition between countries in this product category is positive and has resulted in deeper integration.

This product category, in comparison to other categories offers a wider range of products with different level of processing. Therefore, it allows countries to diversify their products and the degree of integration for this product category is considered the highest in the agriculture industry given the pairs of countries with significant RCA values.

For the three product categories above which mainly recorded the pairs with significant RCA values, a few different patterns can be observed as follows: 


\subsection{High Level of Integration - Trade Creating}

a) Product of HS120 - Ground Nuts, Seeds, Oil Seeds, Soya Beans etc. showed the highest level of integration, recording the most pairs of countries with significant RCA values that did not negatively impact the competition within ASEAN and this was also supported with higher IIT values.

b) Product of HS070 - Cabbages, Cauliflowers, Vegetables, Potatoes. Lettuce, Carrots, Turnips also showed a high level of integration, recording both significant RCA and IIT values. This is with the exception of the steep competition between Philippines and Vietnam in the Indonesian market.

\subsection{Complementary - Trade Creating}

a) Product of HS090 that mainly involves the coffee and tea products showed that although Vietnam and Indonesia as main exporters for these products compete with each other in the ASEAN market, both countries did not show any pattern of causing the other country to lose its competitiveness.

\subsection{High Degree of Competition - Trade Diverting}

a) Product of HS100, which mainly consist of rice, the main export in agriculture, showed a high degree of competition between Vietnam and Thailand. The trend of significant RCA values showed that Thailand in most cases was losing its competitiveness to Vietnam.

b) Product of HS110, similarly also showed a high degree of competition between Vietnam and Thailand, however, Thailand is still able to be competitive in large market such as Indonesia.

During the period of investigation, ASEAN-5 countries have shown different trends of competitiveness for each product categories in the agriculture industry. This competitiveness and some of the product categories, which did not even show any level of significant competitiveness, reflects that there are policy mismatch that curbs further integration in the agriculture industry.

One of the remaining issues that are faced by the agriculture industry in ASEAN is the expectation of individual countries to adhere to different trade liberalisation schedules. The agriculture products in ASEAN, unlike other industries, were mostly not included in the CEPT scheme or if included, the tariffs are absolutely high. This needs structural reforms in policies for individual ASEAN countries to allow national policies that foster and capitalises ASEAN as a competitive exporter of agriculture products especially in encouraging increased food security in the region. Cooperation at ASEAN alone without change in national policies would not create the opportunity for ASEAN to position as a competitive agriculture exporter to the rest of the world.

Countries would also need to consider more flexible and accommodating regulatory policies to handle cross border issues for the agriculture industry. Most agriculture produces are cheaper direct consumer products that travel from one country to another more informally. These cross border trade activities can be improved by integrative policies that can legitimise such activities.

Public-private partnership that involves cross border investments between ASEAN countries would also be necessary to enhance productivity and research. ASEAN countries need to create specialisation by focusing on products that they are competitive in and this focus can be strengthened when investment policies between countries in ASEAN is more relaxed and flexible. One country that lets go of their predominantly large export, for example black tea, to produce green tea should enable the producer of black tea in that particular country to invest in another country within ASEAN that specializes in black tea. However, the problem in the agriculture industry in most ASEAN countries is investments in agriculture industry are highly protected by government and cross border investments rarely take place.

The benefits of a more integrated agriculture industry in ASEAN can have spillover effects if ASEAN is well integrated. One most important aspect to be more integrated will be to adopt standardisations. Exports out of ASEAN should be able to meet the international standards and as proven today, countries like Thailand particularly is able to adhere to several international standards that has elevated the industry in Thailand from 1990s to today. Learning from this experience, with the capacity of integrated ASEAN countries, it would be able for ASEAN to compete with countries like China or Brazil. One good example is the Australia-New Zealand Closer Economic Relations Trade Agreement (ANZCERTA), which was able to increase agriculture trade between Australia and New Zealand although both countries have similar products.

In making ASEAN a single market and production base of the world market with free flow of goods, services, investment and freer flow of capital, the agriculture industry in ASEAN needs to face the challenge of streamlining member countries based on their competitiveness and how to address issues arising from loss of production in certain products to domestic market and the period of adjusting to it. Furthermore, a more 
integrated ASEAN agriculture industry would enable ASEAN to collectively expand an integrated market and complement with other larger economies in East Asia such China, Republic of Korea and Japan that will make a stronger force in international trade.

\section{References}

ASEAN Secretariat Statistics Database. (2015, September 10). ASEAN Secretariat Statistics Database. Retrieved September 10, 2015 from http://aseanstats.asean.org/

ASEAN Secretariat. (2015, September 10). Official Website of the ASEAN Secretariat. Retrieved September 10, 2015 from http://www.asean.org

ASEAN Secretariat. (2015, September 28). ASEAN Secretariat. Retrieved September 28, 2015 from http://www.asean.org/images/2013/economic/afta/Annex\%208\%20amended\%20ATIGA\%20Operational\%2 0Certification\%20Procedures.pdf

Balassa, B. (1977). Revealed Comparative Advantage Revisited: An Analysis of Relative Export Shares of In dustrial Countries, 1953-1971. The Manchester School of Economic\& Social Studies , 45(4), 327-344. https://doi.org/10.1111/j.1467-9957.1977.tb00701.x

Chemsripong, S. (2010). Regional Integration and Intra-Industry Trade in Manufactures between Thailand and Other APEC Countries. The Singapore Economic Review, 54(1), 135-148. https://doi.org/10.1142/S0217590809003148

Xinshen, D., Roe, T., \& Somwaru, A. (2001). What is the Cause of Growth in Regional Trade: Trade Liberalization or RTAs? The Case of Agriculture. The World Economy, 24(1), 51-79. https://doi.org/10.1111/1467-9701.00343

Hansson, P. (1989). Intra-Industry Trade: Measurements, Determinants and Growth. Ume University, Solfjärden $\mathrm{AB}$.

Ilyas, M., Mukhtar, T., \& Tariq, J. M. (2009). Competitiveness among Asian Exporters in the World Rice Market. The Pakistan Development Review, 48(4).

International Trade Centre. (2015, August 15). ITC- Trade Map. Retrieved August 18, 2015 from http://www.intracen.org/tradestat

Krueger, S. (1991). The Political Economy of Agricultural Pricing Policy. The World Bank.

Krugman, P. (1995). Growing World Trade: Causes and Consequences. Brookings Papers on Economic Activity. https://doi.org/10.2307/2534577

Pholphirul, P. (2010). Does AFTA Create More Trade for Thailand? An Investigation of Some Key Trade Indicators. Journal of Current Southeast Asian Affairs, 29(1), 51-78.

Tan, J. C. (2005). The Liberalisation of Trade in Textile and Clothing China's Impact on the ASEAN Economies . Stanford University, Department of Economics.

Whalley, J. (2006). The Post MFA Performance of Developing Asia. NBER Working Paper No. 12178. https://doi.org/10.3386/w12178

\section{Note}

Note 1. ASEAN-5 for this study is limited to Malaysia, Thailand, Indonesia, Philippines and Vietnam.

\section{Copyrights}

Copyright for this article is retained by the author(s), with first publication rights granted to the journal.

This is an open-access article distributed under the terms and conditions of the Creative Commons Attribution license (http://creativecommons.org/licenses/by/4.0/). 